\title{
Analisis Kepemimpinan Kepala Desa Sukamulya Kecamatan Rumpin
}

\section{Kabupaten Bogor}

\author{
I Nyoman Marayasa \\ Dosen Fakultas Ekonomi Universitas Pamulang \\ Email : marayasa569@gmail.com
}

\begin{abstract}
ABSTRAK
Tujuan penelitian ini adalah untuk mengetahui Bagaimana kepemimpinan Kepala Desa Sukamulya

Teknik analisis yang di gunakan dalam penelitian ini adalah teknik analisis kualitatif yaitu prosedur penelitian yang menghasilkan data deskriptif berupa kata kata tertulis maupun lisan. Pendekatan dalam metode analisis ini adalah dengan menggunakan analisis wawancara interaktif ( interaktif model of analyze)

Hasil penelitian adalah sebagai berikut, Sumber daya manusia masyarakat Desa Sukamulya masih tergolong rendah, dapat dilihat bahwa mayoritas penduduknya hanya tamat Sekolah Dasar, mayoritas masyarakat Desa Sukamulya bermata pencaharian sebagai petani tradisional., masih minim sarana kesehatan seperti rumah sakit dan puskesmas sehingga kesadaran masyarakat untuk hidup sehat masih kurang layak, kondisi jalan yang rusak akibat banyaknya truk pengangkut pasir yang beroprasi sehingga minimnya sarana transportasi umum, untuk menghubungkan masyarakat Desa Sukamulya dengan masyarakat lain diluar Desa, lahan kosong disewakan kepada perusahaan eksploitasi pasir sehingga tingat polusi udara semakin kotor
\end{abstract}

Kata Kunci : Kepemimpinan, Kepala Desa 


\section{PENDAHULUAN}

Kepala desa atau sebutan lain sesuai Peraturan Menteri Dalam Negeri Republik Indonesia Nomor 84 Tahun 2015 Tentang Struktur Organisasi dan Tata Kerja Pemerintah Desa, adalah pejabat Pemerintah Desa yang mempunyai wewenang, tugas dan kewajiban untuk menyelenggarakan rumah tangga Desanya dan melaksanakan tugas dari Pemerintah dan Pemerintah Daerah. Masa jabatan kepala desa adalah 6 (enam) tahun, dan dapat diperpanjang lagi untuk 3 (tiga) kali masa jabatan berikutnya berturut-turut atau tidak.Kepala desa tidak bertanggung jawab kepada Camat, namun hanya dikoordinasikan saja oleh Camat. Kepala desa bertanggung jawab atas penyelenggarakan Pemerintahan Desa, pelaksanakan Pembangunan Desa, pembinaan kemasyarakatan Desa, dan pemberdayaan masyarakat Desa .

Kepala Desa umumnya mempunyai peran yang cukup besar dalam pemerintahan desa, terutama untuk desa yang didasarkan pada ikatan daerah bukan desa yang berdasarkan atas ikatan Genealogis (hubungan darah). Kepala Desa sebagai aktor utama dari kepemimpinan lokal dalam pemerintahan desa berdasarkan peraturan perundang-undangan yang berlaku adalah seorang tokoh di desa yang memenuhi berbagai persyaratan, berhasil memenangkan pemilihan (dipilih oleh rakyat desa) dan diangkat oleh Pemerintah Republik Indonesia, sehingga menjadi pemimpin pemerintahan tertinggi di desanya.

Seorang pemimpin tidak hanya dituntut tegas dan sigap dalam menghadapi setiap persoalan yang ada, melainkan juga harus mengerti akan keinginan atau setiap kebutuhan karyawannya. Pemimpin yang bijaksana dan baik harus dapat memberikan kepuasan kepada para bawahannya dan selalu berusaha memperhatikan gairah atau semangat kerja mereka. Tentunya pihak pimpinan harus mempunyai kemampuan dalam mengatur, mengelola, mengarahkan, mempengaruhi. Memerintah dan memotivasi bawahannya untuk memperoleh tujuan yang diinginkan oleh masyarakatnya

Sukamulya adalah desa di kecamatan Rumpin, Bogor, Jawa Barat, Indonesia. berbatasan dengan : Desa Mekar Sari di sebelah Barat, Desa Taman Sari di sebelah Selatan. Berbatasan langsung dengan Tangsel (Tangerang Selatan) atau BSD (Bumi Serpong Damai) di sebelah Utara. Terdapat beberapa pesantren modern, diantaranya : Pondok Pesantren Terpadu Ekonomi Islam Multazam. Selain itu, di desa ini terdapat : LAPAN 1 (Lembaga Penerbangan dan Antariksa Nasional), Bale Tirtawana (cluster Argawana) yang dibangun oleh PT BSD Tbk dan merupakan group Sinarmas Land, Pasar Cicangkal yaitu pasar Tradional yang bernuansa Modern. Terdapat pula SDN Suka Mulya, SMPN 2 Rumpin, MTs dan SMA An Najah, SMP dan SMA Yapira. Kantor Pos Kecamatan Rumpin terdapat di desa ini, yang lokasinya di depan Kantor Desa Suka Mulya.

Wilayah ini sangat memprihatinkan, dimana jalan yang dilalui (Jalan Cisauk-SuraditaCicangkal-Lebak Wangi-Kadaka) rusak parah yang diakibatkan banyaknya truk bermuatan pasir dari wilayah Rumpin. Pemda dan Pemerintah Kabupaten Bogor 
sepertinya tidak bereaksi atas rusaknya jalan ini.

Berdasarkan permasalahan diatas maka penulis tertarik untuk menganalisis seberapa besar pengaruh kepemimpinan tersebut untuk meningkatkan kinerja karyawan, sehingga penulis mengambil judul"Analisis Kepemimpinan Kepala Desa Sukamulya Kecamatan Rumpin Kabupaten Bogor".

\section{B. Rumusan Masalah}

Dari penjelasan yang dikemukakan dalam latar belakang di atas,mengenai mengapa penelitian ini harus dilaksanakan, dapat diambil sebuahrumusan masalah pokok dari penelitian ini yaitu :

"Bagaimana kepemimpinan Kepala Desa Sukamulya?

\section{Tujuan Penelitian}

Untuk mengetahui Bagaimana kepemimpinan Kepala Desa Sukamulya

\section{Manfaat Penelitian}

1. Dapat memberikan manfaat bagi Kepala Desa dalam mengelola pemerintahan desanya menyangkut fungsi dan perannya sebagai pemimpin formal desa dalam meningkatkan mutu atau kualitas pembangunan Desa

2. Dari penelitian ini, penulis mengharapkan agar kepala desa berperan aktif dalam membangun masyarakat desa di desa Sukamulya

\section{TINJAUAN PUSTAKA}

\section{a) Kepemimpinan}

Kepemimpinan mempunyai arti yang berbeda-beda untuk tiap- tiap orang. Sebagai akibatnya, banyak istilah mengenai kepemimpinan, misalnya kepemimpinan sebagai satu kekuatan, hak atau wewenang, pengaruh terhadap orang lain, pola interaksi, persepsi orang lain terhadap batasan dari pengaruh.

Kepemimpinan seorang pemimpin adalah unik dapat diwariskan secara otomatis. Setiap pemimpin memiliki karakteristik tertentu yang timbul pada situasi yang berbeda. Kepemimpinan yang sesuai dengan keadaan perusahaan dan keinginan karyawan akan mendorong peningkatan kinerja karyawan dalam pencapaian sasaran dan tujuan perusahaan dalam pelaksanaan kegiatannya para pemimpin mempunyai cara tersendiri untuk mempengaruhi dan mengarahkan karyawannya, sehingga diharapkan mau bersamasama berusaha mencapai tujuan perusahaan melalui pelaksanaan pekerjaan yang telah ditentukan. Definisi kepemimpinan sangat bervariasi, sebanding dengan banyak orang yang mencoba mendefinsikan konsep kepemimpinan. Peter Northouse dalam Rowe dan Guerrero(2011:1) mengemukakan sebagian besar definisi kepemipinan proses dimana seorang individu mempengarui sekelompok individu untuk mencapai tujuan bersama.Wood ( 2000:314), pengaruh interpersonal yang menyebabkan skelompok orang melakukan apa yang dikehendaki oleh pemimpin atau manajer untuk dilakukan. Merton dalam Hughes ( 2012:4), hubungan interpersonal di mana orang lain 
melakukan perintah karena mereka ingin, bukan karena terpaksa.

Menurut Hasibuan (2007:13) berpendapat bahwa kepemimpinan adalah seseorang yang mempergunakan wewenang dan kepemimpinannya untuk mengarahkan orang lain serta bertanggung jawab atas pekerjaan orang tersebut dalam mencapai suatu tujuan.

Danang Sunyoto (2012:34), berpendapat bahwa kepemimpinan adalah sebuah organisasi sifat dan sikap kepemimpinan seseorang pemimpin untuk mempengaruhi orang lain sangat menentukan di dalam mencapai tujuan organisasi.

Handoko (2009:294), berpendapat bahwa kepemimpinan adalah kemampuan yang dipunya seseorang untuk mempengaruhi orang-orang lain agar bekerja mencapai tujuan dan sasaran.

Dari berbagai pengertian diatas maka dapat diambil kesimpulan bahwa kepemimpinan adalah kemampuan seorang pemimpin untuk dapat mempengaruhi dan menggerakan orang lain untuk bekerjasama dalam mencapai suatu tujuan.

\section{b) Kepala Desa}

Secara eksplisit Pasal 26 ayat (1) mengatur empat tugas utama Kepala Desa yaitu: Menyelenggarakan pemerintahan desa, (ii) Melaksanakan pembangunan desa, (iii) Melaksanakan pembinaan masyarakat desa; dan, (iv) Memberdayakan masyarakat desa. Dengan tugas yang diberikan, Kepala Desa diharapkan bisa membawa desa ke arah yang diharapkan oleh UU ini.

Pasal 26 Ayat (1)

Kepala Desa bertugas menyelenggarakan pemerintahan desa, melaksanakan pembangunan desa, pembinaan kemasyarakatan desa, dan pemberdayaan masyarakat desa.

Penjelasan : Cukup jelas

Ayat (2)

Dalam melaksanakan tugas sebagaimana dimaksud pada ayat (1), Kepala Desa berwenang:

a. Memimpin penyelenggaraan pemerintahan desa.

b. Mengangkat dan memberhentikan Kepala Desa.

c. Memegang kekuasaaan pengelolaan keuangan dan aset desa.

d. Menetapkan peraturan desa.

e. Menetapkan anggaran dan pendapatan belanja desa.I

f. Membina kehidupan masyarakat desa

g. Membina ketentramana dan ketertiban masyarakat desa

h. Membina dan meningkatkan perekonimian desa serta mengintegrasikannya agar mencapai skala produktif untuk sebesar-besarnya kemakmuran desa.

i. Mengembangkan sumber pendapatan desa.

j. Mengusulkan dan menerima pelimpahan sebagian kekayaan negara guna meningkatkan kesejahteraan masyarakat desa.

k. Mengembangkan kehidupan sosial budaya masyarakat desa.

1. Memanfaatkan teknologi tepat guna. 
m. Mengoordinasikan

pembangunan desa secara partisipatif.

n. Mewakili desa di dalam dan di luar pengadilan atau menunjuk kuasa hukum untuk mewakilinya sesuai dengan ketentuan peraturan perundang-undangan;

o. Melaksanakan wewenang lain yang sesuai dengan ketentuan peraturan perundang-undangan.

Penjelasan : Cukup jelas

Ayat (3)

Dalam melaksanakan tugas sebagaimana dimaksud pada ayat (1), Kepala Desa berhak:

a. Mengusulkan struktur organisasi dan tata kerja Pemerintah Desa.

b. Mengajukan rancangan dan menetapkan Peraturan Desa;

c. Menerima penghasilan tetap setiap bulan, tunjangan, dan penerimaan lainnya yang sah, serta mendapat jaminan kesehatan.

d. Mendapatkan perlindungan hukum atas kebijakan yang dilaksanakan; dan

e. Memberikan mandat pelaksanaan tugas dan kewajiban lainnya kepada perangkat desa.

Penjelasan

Semua cukup Jelas kecuali Huruf c. Jaminan kesehatan yang diberikan kepada Kepala Desa diintegrasikan dengan jaminan pelayanan yang dilakukan oleh pemerintah pusat sesuai dengan ketentuan peraturan perundang-undangan.

Ayat (4)

Dalam melaksanakan tugas sebagaimana dimaksud pada ayat (1), Kepala Desa berkewajiban: a. Memegang teguh mengamalkan Pancasila, melaksanakan Undang-undang Dasar negara Republik Indonesia tahun 1945, serta mempertahankan dan memelihara keutuhan Negara Kesatuan Republik Indonesia, dan Bhineka Tunggal Ika.

b. Meningkatkan kesejahteraan masyarakat Desa;

c. Memelihara ketentraman dan ketertiban masyarakat desa;

d. Menaati dan menegaskkan peraturan perundang-undangan;

e. Melaksanakan kehidupan demokrasi dan berkeadilan gender;

f. Melaksanakan prinsip tata pemerintahan desa yang akuntabel, transparan, profesional, efektif dan efisien, bersih, serta bebas dari kolusi, korupsi, dan nepotisme;

g. Menjalin kerjasama dan koordinasi dengan seluruh pemangku kepentingan di desa;

h. Menyelenggarakan administrasi Pemerintahan Desa yang baik;

i. Mengelola keuangan dan aset desa;

j. Melaksanakan urusan pemerintahan yang menjadi kewenangan desa;

k. Menyelesaikan perselisihan masyarakat di desa;

1. Mengembangkan perekonomian masyarakat desa;

m. Membina dan melestarikan nilai sosial budaya masyarakat desa;

n. Memberdayakan masyarakat dan lembaga kemasyarakatan di Desa;

o. Mengembangkan potensi sumber daya alam dan melestarikan lingkungan hidup; dan 
memberikan informasi kepada masyarakat Desa; dan

p. Memberikan informasi kepada masyarakat desa.

Penjelasan : Cukup jelas

Pembahasan di DPR

Pembahasan tentang Kepala Desa masuk di dalam rumusan Naskah Akademik RUU Desa. Disebutkan dalam Naskah Akademik, desa menjadi arena politik terdekat bagi relasi antara masyarakat dengan perangkat desa yang menjadi pemegang kekuasaan. Karena desa menjadi sentrum kekuasaan politik, maka Kepala Desa merupakan personifikasi dan representasi pemerintah desa. Tugas penting pemerintah desa adalah memberi pelayanan administratif (suratmenyurat) kepada warga.

Di dalam DIM (Oktober 2012), pengaturan Kepala Desa masuk dalam Bagian Pemerintahan Desa, terdiri dari 19 Pasal (Pasal 22-40). Pengaturan tentang pemilihan Kepala Desa, pemberhentian Kepala Desa, BPD, dan Musyawarah Desa diatur dalam Bab tersendiri. Akan tetapi dalam UU Desa, pengaturan Pemerintahan Desa menjadi 42 pasal yang menggabungkan pengaturan tentang pemilihan Kepala Desa, pemberhentian Kepala Desa, BPD, dan Musyawarah Desa dalam satu bab, yaitu $\mathrm{Bab} \mathrm{V}$ Penyelenggaraan Pemerintah Desa.

Dalam proses pembahasan RUU di DPR, rumusan tentang Kepala Desa tidak banyak mengalami perubahan. Perubahan hanya berkisar pada penggantian istilah, perubahan nomor pasal, dan ada sedikit usulan penambahan pasal. Tidak ada perdebatan yang cukup signifikan dalam pembahasan Kepala Desa oleh fraksi-fraksi. Hanya ada beberapa point saja yang menjadi perdebatan, yaitu:

a. Wewenang Kepala Desa mengangkat dan memberhentikan perangkat desa (pasal 26 ayat (2) huruf c). Dalam rumusan RUU, mengangkat dan memberhentikan perangkat desa menjadi hak Kepala Desa, bukan wewenang Kepala Desa. Akan tetapi, dalam UU ini hak Kepala Desa hanya mengusulkan pengangkatan dan pemberhentian perangkat desa kepada Camat. Perdebatan masalah ini ada pada apakah pemberhentian dan pengangkatan perangkat desa harus disampaikan kepada Camat?. Sebagian besar fraksi setuju, tetapi Fraksi FPP menyatakan pengangkatan dan pemberhentian perangkat desa haruslah menjadi hak mutlak dari seorang Kepala Desa, agar Kepala Desa dapat memilih perangkat desa yang berkompeten dan mampu bekerjasama. Meskipun sebetulnya hal ini tidak bisa dilepaskan dengan kemungkinan adanya nepotisme dalam pengangkatan perangkat desa. Fraksi FPD mengusulkan perlunya dasar hukum yang dipegang oleh Kepala Desa ketika ia memberhentikan perangkat desa. Hal ini untuk menghindari kesewenang-wenangan Kepala Desa, misalnya hanya karena persoalan perbedaan pendapat.

Dalam RDPU yang digelar pada tanggal 10 Oktober 2012, H Anwar Maksum dari Forum Wali Nagari Sumatera Barat (Forwana Sumbar) 
pandangannya bahwa kewenangan Kepala Desa dalam mengangkat dan memberhentikan perangkat desa telah diamputasi oleh RUU desa. Hal ini jelas bertentangan dengan kedudukan desa sebagai self company community yang diakui oleh RUU ini. Oleh karena itu, Forwana merekomendasikan pengangkatan dan pemberhentian perangkat desa menjadi kewenangannya Kepala Desa, bukan kewenangan Camat berdasarkan usulan Kepala Desa. Untuk menghindari kesewenangwenangan Kepala Desa, maka perlu diatur tata cara pengangkatan dan pemberhentian perangkat desa melalui PP.

b. Wewenang Kepala Desa dalam menetapkan Perdes (pasal 26 ayat (2) huruf d). Di dalam RUU salah satu kewenangan Kepala Desa adalah menetapkan Peraturan Desa setelah dimusyawarahkan bersama dengan BPD. Fraksi FPD dan FPPP mengusulkan penetapan Perdes oleh Kepala Desa dilakukan setelah dimusyawarahkan dan disepakati bersama dengan BPD. Alasannya bahwa BPD merupakan representasi masyarakat desa, maka kebijakan dan keputusan Kepala Desa harus mendapat persetujuan BPD. Dalam UU Desa, usulan ini tidak masuk. Akan tetapi pasal 55, menyebutkan salah satu fungsi BPD adalah membahas dan menyepakati rancangan Perdes bersama Kepala Desa.

Pada rapat kerja Pansus tanggal 11 Desember 2013, Dewan Perwakilan Daerah (DPD) RI memberikan pandangannya di dalam Pendapat Mini DPD terhadap RUU Desa mengenai perlunya pengaturan yang memberi kewenangan kepada lembaga kemasyarakatan untuk menyelesaikan pertikaian antar warga. Kewenangan komunitas tersebut berbeda dengan berbagai kewenangan pembinaan ketertiban dan ketenteraman oleh Desa atau kewenangan penyelesaian sengketa masyarakat oleh Kepala Desa yang merupakan perangkat birokrasi. Hal ini dimaksudkan agar permasalahan pelanggaran hukum ringan yang melibatkan warga dapat diselesaikan di level komunitas.

\section{Tanggapan}

Kepala Desa merupakan representasi pemerintah desa. Ia menjadi aktor penting dalam pembangunan desa. Oleh karena itu, tugas, wewenang dan tanggungjawab Kepala Desa diatur secara detail dalam UU Desa. Semangat UU Desa menempatkan Kepala Desa bukan kepanjangan tangan pemerintah, melainkan sebagai pemimpin masyarakat. Kepala Desa harus mengakar dengan masyarakat, melindungi, mengayomi, dan melayani masyarakat. Tugas Kepala Desa bukan sekadar menyelenggarakan pemerintahan desa, tetapi ia juga melakukan pemberdayaan kepada masyarakat desa.

Dilihat dari konstruksi gabungan pemerintahan desa, sebagaimana disebut dalam Penjelasan Umum UU Desa, Kepala Desa menempati posisi sentral. Namun posisi sentral ini bukan tanpa tantangan jika dihubungkan dengan tugas, hak dan kewenangan yang 
dimilikinya. Misalnya, jika terjadi benturan kepentingan antara masyarakat desa dengan pemerintah kabupaten/kota, bagaimana Kepala Desa menempatkan posisi yang ideal? Apakah ia lebih memihak masyarakat desa atau sebaliknya?

Tugas Kepala Desa dalam UU Desa diatur dalam pasal 26 ayat (1) disebutkan: "Kepala Desa bertugas menyelenggarakan pemerintahan desa, melaksanakan pembangunan desa, pembinaan kemasyarakatan desa, dan pemberdayaan masyarakat desa”.

UU Desa ingin membedakan antara tugas, hak, kewajiban, dan tanggung jawab Kepala Desa. Karena itu, dalam UU Desa pengaturan mengenai tugas, wewenang, hak, dan kewajiban Kepala Desa diatur secara detail. Hal ini berbeda dengan UU No. 22/1999 tentang Pemerintahan Daerah, yang menggabungkan tugas dan kewajiban Kepala Desa diatur dalam satu pasal (pasal 101). Di UU No. 22/1999, terdapat 6 tugas dan kewajiban Kepala Desa, yaitu: 1) memimpin penyelenggaraan pemerintahan desa; 2) membina kehidupan masyarakat desa; 3) membina perekonomian desa; 4) memelihara ketentraman dan ketertiban masyarakat desa; 5) mendamaikan perselisihan masyarakat di desa; dan 6) mewakili desanya di dalam dan di luar pengadilan dan dapat menunjuk kuasa hukumnya. Beberapa tugas Kepala Desa yang ada dalam UU No. 22/1999 menjadi kewenangan Kepala Desa dalam UU Desa.

Undang-Undang No. 32 Tahun 2004 yang menggantikan UU No.
22/1999 tidak mengatur secara detail mengenai pengaturan tentang Kepala Desa Pasal 208 menyebutkan: "Tugas dan kewajiban Kepala Desa dalam memimpin penyelenggaraan pemerintah desa diatur lebih lanjut dengan Perda berdasarkan Peraturan Pemerintah". Tetapi, pengaturan lebih jauh tentang tugas dan kewajiban Kepala Desa dapat dilihat dalam PP No. 72/2005 tentang Desa.

Wewenang Kepala Desa yang ada dalam UU Desa (pasal 26 ayat 2) dapat dibagi dalam empat fungsi, yaitu:

Fungsi pemerintahan, meliputi: (i) memimpin penyelenggaraan pemerintahan Desa; (ii) mengangkat dan memberhentikan perangkat desa; (iii) memegang kekuasaaan pengelolaan keuangan dan aset desa; (iv) pemanfaatan teknologi tepat guna; dan (v) mengkordinasikan pembangunan desa secara partisipatif. Dua kewenangan terakhir ini sebetulnya menjadi cara Kepala Desa dalam penyelenggaraan pembangunan desa yang harus dilakukan secara partisipatif dan memanfaatkan teknologi tepat guna.

Fungsi regulasi, meliputi (i) menetapkan APB Desa; dan (ii) menetapkan Perdes. Dalam melaksanakan kedua wewenang ini, Kepala Desa tidak bisa menetapkan sendiri APB Desa dan Perdes. Pembahasan dan penetapan Perdes dilakukan bersama dengan BPD (pasal 55 dan 69 UU Desa).

Fungsi ekonomi, meliputi: (i) mengembangkan sumber pendapatan Desa; dan (ii) mengusulkan dan menerima pelimpahan sebagian kekayaan negara guna meningkatkan kesejahteraan masyarakat Desa. 
Fungsi sosial, meliputi: (i) membina kehidupan masyarakat Desa; (ii) mengembangkan kehidupan sosial budaya masyarakat Desa; dan (iii) membina ketenteraman dan ketertiban masyarakat Desa.

Belasan kewenangan Kepala Desa dalam pasal 26 ayat (2) telah mendukung visi UU Desa yang ingin menciptakan desa yang kuat, maju, mandiri, dan demokratis untuk mencapai masyarakat yang adil, makmur, dan sejahtera. Akan tetapi, ini sangat tergantung dari kinerja Kepala Desa itu sendiri. Sejauhmana ia dapat menggerakkan, memotivasi, berkomunikasi, merencanakan, dan melaksanakan pembangunan yang ada di lingkungannya. Oleh karena itu, kapasitas menjadi penting dimiliki oleh seorang Kepala Desa. Sayangnya, kapasitas Kepala Desa maupun perangkat desa tidak menjadi perhatian UU ini. Pasal 26 ayat (3) tentang hak Kepala Desa disebutkan: "dalam melaksanakan tugas sebagaimana dimaksud pada ayat (1), Kepala Desa berhak: a. mengusulkan struktur organisasi dan tata kerja Pemerintah Desa; b. Mengajukan rancangan dan menetapkan Peraturan Desa; c. Menerima penghasilan tetap setiap bulan, tunjangan, dan penerimaan lainnya yang sah, serta mendapat jaminan kesehatan; $d$. Memberikan mandat pelaksanaan tugas dan kewajiban lainnya kepada perangkat desa.

Dalam klausul di atas tidak
disebutkan bahwa peningkatan
kapasitas menjadi bagian dari hak
Kepala Desa. Padahal dalam rumusan
Naskah Akademik RUU Desa,
kapasitas perangkat desa menjadi

salah permasalahan dari penyelenggaraan pemerintahan Desa. Selama ini Kepala Desa dan perangkat Desa tidak mendapatkan pendidikan dan latihan yang sistematis dan berkelanjutan seperti halnya Pegawai Negeri Sipil (PNS) dan pejabat yang lain. Tidak diaturnya peningkatan kapasitas Kepala Desa dan perangkat Desa, dapat menjadi hambatan untuk kinerja pemerintahan desa, karena rendahnya kapasitas Kepala Desa dan perangkat Desa.

Mengenai kapasitas ini, Pasal 112 UU Desa memberikan tugas kepada Pemerintah, pemerintah Daerah Provinsi, Kabupaten/Kota memberdayakan masyarakat desa antara lain dengan meningkatkan kualitas pemerintahan dan masyarakat desa melalui pendidikan, pelatihan, dan penyuluhan.

Sutoro Eko (2013) membagi lima bentuk kapasitas Desa (termasuk di dalamnya Kepala Desa) yang perlu dikembangkan dalam rangka membangun otonomi desa. Pertama, kapasitas regulasi (mengatur), yaitu kemampuan pemerintah desa mengatur kehidupan desa beserta isinya (wilayah, kekayaan, dan penduduk) dengan Perdes berdasarkan kebutuhan dan aspirasi masyarakat setempat. Kedua, kapasitas ekstraksi, yaitu kemampuan mengumpulkan, mengerahkan, dan mengoptimalkan aset-aset desa untuk menopang kebutuhan (kepentingan) pemerintah dan warga masyarakat desa. Ketiga, kapasitas distributif, yaitu kemampuan pemerintah desa membagi sumberdaya desa secara seimbang dan merata sesuai dengan prioritas kebutuhan masyarakat desa. Keempat, kapasitas 
responsif, yaitu kemampuan untuk peka atau memiliki daya tanggap terhadap aspirasi atau kebutuhan warga masyarakat untuk dijadikan sebagai basis dalam perencanaan kebijakan pembangunan. Kelima, kapasitas jaringan dan kerjasama, yaitu kemampuan mengembangkan jaringan kerjasama dengan pihakpihak luar dalam rangka mendukung kapasitas ekstraksi.

\section{METODE PENELITIAN}

A. Metode Penelitian

Metode penelitian dengan menggunakan Metode Penelitian Kualitatif. Dengan metode kualitatif penulis mempunyai kesempatan yang lebih luas dalam berinteraksi dengan objek penelitian, sehingga dapat memperkaya dan memperdalam kajian dalam penelitian yang penulis lakukan.

B. Lokasi Penelitian

Penelitian dilakukan di Desa Cimerak Kecamatan Cimerak Kabupaten Pangandaran.

C. Sasaran Penelitian

Sasaran penelitian yang dituju adalah Kepala Desa Sukamulya

\section{Fokus Penelitian}

Penulis melakukan fokus penelitian terhadap Peranan Kepemimpinan Kepala Desa Sukamulya

\section{E. Pendekatan Dalam Penelitian}

Pendekatan yang digunakan dalam melakukan penelitian ini adalah studi kasus. Studi kasus diartikan sebagai metode atau strategi dalam penelitian, bisa juga berarti hasil dari suatu penelitian kasus tertentu. Studi kasus adalah suatu pendekatan untuk mempelajari, menerangkan, atau menginterpretasi suatu kasus dalam konteksnya secara natural tanpa adanya intervensi dari pihak luar.

F. Teknik Penetapan Sample

Penulis menggunakan teknik "purposive sampling" dalam pengambilan sample. Purposive sampling termasuk sample jenis non probability sampling, yaitu tidak memberikan kesempatan yang sama kepada setiap objek penelitian untuk dijadikan informan. Dalam penelitian ini penulis menentukan sample melalui pertimbangan tersendiri yang dipandang dapat memberikan data hingga mencapai titik jenuh (saturasi) agar pada akhirnya dapat ditarik kesimpulan.

\section{G. Teknik Pengumpulan Data}

\section{Data primer}

Data primer adalah data yang diperoleh secara langsung dari responden dengan menggunakan teknik wawancara mendalam dan intensif dengan para informan.

\section{Data sekunder}

Data sekunder adalah data yang diperoleh buku-buku, dokumen, leteratur, media masa dan sumbersumber media cetak lainnya.

Pengumpulan data selain menggunakan sample, peneliti juga menggunakan teknik Wawancara Mendalam (in depth interview), Menurut Miles dan Huberman adalah wawancara informal yang dilakukan pada saat konteks yang dianggap tepat guna mendapatkan data yang mempunyai kedalaman dan dapat dilakukan berkali-kali secara frekuentif sesuai dengan keperluan penelitian Teknik ini 
dimaksudkan agar peneliti mampu mengeksplorasi data dari informan dan pewawancara akan mempengaruhi pada jawaban yang diberikan informan. Cara pengambilan data dengan tanya jawab dengan informan yang dilakukan dengan wawancara mendalam.

\section{Teknik Analisa Data}

Teknik analisis yang di gunakan dalam penelitian ini adalah teknik analisis

kualitatif yaitu prosedur penelitian yang menghasilkan data deskriptif berupa kata - kata tertulis maupun lisan. Pendekatan dalam metode analisis ini adalah dengan menggunakan analisis wawancara interaktif ( interaktif model of analyze)

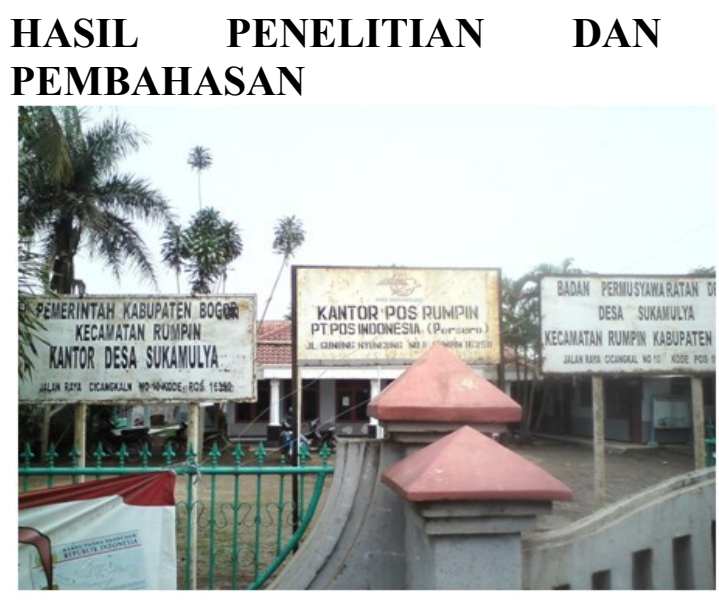

Desa Sukamulya adalah salah satu desa di Kecamatan Rumpin Kabupaten Bogor. Luas wilayah desa ini 1.070 Ha dengan Lurah bernama Bapak Suganda HM. Batasan wilayah desa ini yaitu

- Sebelah utara : Desa Suradita

- Sebelah selatan : Desa Tamansari

- Sebelah timur : Desa Gunung Sindur

- Sebelah barat : Desa Mekarsari

Dari survey yang telah dilakukan, diperoleh data sebagai berikut :

\section{A. Sumber Daya Manusia}

\section{Tabel 4.1}

Sumber Daya Manusia

\begin{tabular}{|l|l|}
\hline Jumlah laki-laki & 6659 orang \\
\hline $\begin{array}{l}\text { Jumlah } \\
\text { perempuan }\end{array}$ & 6210 orang \\
\hline Jumlah total & 12869 orang \\
\hline $\begin{array}{l}\text { Jumlah kepala } \\
\text { keluarga }\end{array}$ & $3012 \mathrm{KK}$ \\
\hline
\end{tabular}

Sumber : Data Desa Sukamulya

Dari data diatas dapat dilihat jumlah warga laki-laki lebih banyak daripada perempuan, selain perlunya ditingkatkan keterampilan laki-laki dalam mengelola desa maka dibutuhkan pemberdayaan perempuan untuk dapat meningkatkan kesejahteraan keluarga dengan menambah penghasilan dari sektor usaha kecil atau usaha rumah tangga.

Tabel 4.2

Tingkat Pendidikan

\begin{tabular}{|c|c|c|}
\hline Tingkat Pendidikan & Laki-laki & Perempuan \\
\hline Usia 3-6 tahun yang belum masuk TK & 206 & 251 \\
\hline Usia 3-6 tahun yang sedang TK/Play group & 241 & 201 \\
\hline Usia 7-18 tahun yang tidak pernah sekolah & - & - \\
\hline Usia 7-18 tahun yang sedang sekolah & 1575 & 1432 \\
\hline Usia 18-56 tahun tidak pernah sekolah & - & - \\
\hline Usia 18-56 tahun pernah SD tapi tidak tamat & 216 & 322 \\
\hline
\end{tabular}




\begin{tabular}{|c|c|c|}
\hline Tamat SD/sederajat & 1273 & 1305 \\
\hline Jumlah usia 12-56 tahun tidak tamat SMP & 172 & 175 \\
\hline Jumlah usia 18-56 tahun tidak tamat SMA & 136 & 113 \\
\hline Tamat SMP/sederajat & 997 & 781 \\
\hline Tamat SMA/sederajat & 1123 & 792 \\
\hline Tamat D-1/sederajat & - & - \\
\hline Tamat D-2/sederajat & 22 & 24 \\
\hline Tamat D-3/sederajat & 5 & 26 \\
\hline Tamat S-1/sederajat & 289 & 262 \\
\hline Tamat S-2/sederajat & 35 & 5 \\
\hline Tamat S-3/sederajat & 1 & - \\
\hline Tamat SLB A & - & - \\
\hline Tamat SLB B & - & - \\
\hline Tamat SLB C & - & - \\
\hline Jumlah & 6659 & 6210 \\
\hline
\end{tabular}

\section{Sumber : Data Desa Sukamulya}

Masyarakat Desa Sukamulya masih tergolong rendah, hal ini perlu dalam lingkup pendidikan masih ditingkatkan dengan peran serta kepala tergolong rendah, hal ini dapat dilihat desa selaku pimpinan, untuk dapat dari tabel diatas, masyarakan dengan memfasilitasi para warganya untuk pendidikan jenjang perguruan tinggi mendapatkan pendidikan tinggi.

Tabel 4.3

Mata Pencaharian

\begin{tabular}{|c|c|c|}
\hline Jenis Pekerjaan & Laki-laki & Perempuan \\
\hline Petani & 432 & 295 \\
\hline Buruh tani & 164 & 100 \\
\hline Buruh migran perempuan & - & - \\
\hline Buruh migran laki-laki & - & - \\
\hline PNS & 429 & 75 \\
\hline Pengrajin industry rumah tangga & 54 & 40 \\
\hline Pedagang keliling & 168 & 215 \\
\hline Peternak & 54 & - \\
\hline Nelayan & - & - \\
\hline Montir & 126 & - \\
\hline Dokter swasta & - & 1 \\
\hline Bidan swasta & - & 3 \\
\hline Perawat swasta & - & 2 \\
\hline Pembantu rumah tangga & - & 151 \\
\hline TNI & 4 & - \\
\hline POLRI & 1 & - \\
\hline Pensiunan PNS/TNI/POLRI & 17 & 4 \\
\hline
\end{tabular}




\begin{tabular}{|c|c|c|}
\hline Pengusaha kecil dan menengah & 6 & 1 \\
\hline Pengacara & - & - \\
\hline Notaris & - & - \\
\hline Dukun kampong & - & 5 \\
\hline Jasa pengobatan alternative & 4 & 2 \\
\hline Dosen swasta & 1 & - \\
\hline Pengusaha besar & - & - \\
\hline Arsitektur & - & - \\
\hline Seniman & - & - \\
\hline
\end{tabular}

\section{Sumber : Data Desa Sukamulya}

Dari tabel diatas jumlah petani dan buruh tani mendominasi mata pencaharian masyarakat Desa Sukamulya, hal ini perlu adanya dorongan dariKepala Desa selaku pimpinan, untuk mengembangkan sektor pertanian melalui kelompok usaha tani agar hasil pertanian tersebut dapat lebih baik lagi, disamping itu untuk sektor selain pertanian perlu adanya peningkatan melalui pemanfaatan lahan, pendidikan yang mumpuni, pelatihan dan usaha lainnya untuk mencapai kesejahteraan desa untuk lebih baik dan merata.

Tabel 4.4 Agama

\begin{tabular}{|c|c|c|}
\hline Agama & $\begin{array}{c}\text { Laki- } \\
\text { laki }\end{array}$ & Perempuan \\
\hline Islam & 5645 & 5476 \\
\hline Kristen & 449 & 287 \\
\hline Katolik & 29 & 27 \\
\hline Hindu & 6 & 8 \\
\hline Budha & 231 & 164 \\
\hline Khonghucu & 299 & 248 \\
\hline $\begin{array}{c}\text { Kepercayaan } \\
\text { kepada Tuhan } \\
\text { YME }\end{array}$ & - & - \\
\hline $\begin{array}{c}\text { ALiran } \\
\text { kepercayaan } \\
\text { lain }\end{array}$ & - & - \\
\hline Jumlah & 6659 & 6210 \\
\hline
\end{tabular}

Sumber : Data Desa Sukamulya
Dari tabel diatas, mayoritas masyarakat desa Sukamulya memeluk agama Islam, oleh karenanya kepala desa sebagai pimpinan harus bisa menciptakan suasana yang kondusif, toleransi antar umat beragama agar tercipta keharmonisan.

Tabel 4.5

Etnis

\begin{tabular}{|c|c|c|}
\hline Etnis & $\begin{array}{c}\text { Laki- } \\
\text { laki }\end{array}$ & Perempuan \\
\hline Aceh & 1 & 2 \\
\hline Batak & 15 & 14 \\
\hline Nias & - & - \\
\hline Mentawai & - & - \\
\hline Melayu & - & - \\
\hline Minang & 26 & 21 \\
\hline Kubu & - & - \\
\hline Anak & - & - \\
\hline Dalam & - & - \\
\hline Badui & - & 256 \\
\hline Betawi & 315 & 5436 \\
\hline Sunda & 5696 & 467 \\
\hline Jawa & 589 & 12 \\
\hline Madura & 15 & 2 \\
\hline Bali & 2 & - \\
\hline Banjar & - & - \\
\hline Dayak & - & - \\
\hline Bugis & - & - \\
\hline Makasar & - & - \\
\hline Mandar & - & \\
\hline Suber & & \\
\hline
\end{tabular}

Sumber : Data Desa Sukamulya 
Dari tabel diatas, suku Sunda mendominasi etnis masyarakat desa Sukamulya, sebagai pimpinan, kepala desa harus bisa mempersatukan etnisetnis yang ada diwilayahnya agar tercipta toleransi antar sesama tanpa membedakan ke-suku-annya

\section{B. Sarana dan Prasarana \\ Tabel 4.6 \\ Prasarana Kesehatan}

\begin{tabular}{|c|c|}
\hline Rumah Sakit umum & - \\
\hline Puskesmas & - \\
\hline Puskesmas pembantu & - \\
\hline Balai pengobatan & 2 \\
\hline Apotik & - \\
\hline Posyandu & 10 \\
\hline Toko obat & 2 \\
\hline Balai penobatan swasta & 2 \\
\hline $\begin{array}{c}\text { Gudang penyimpanan } \\
\text { obat }\end{array}$ & - \\
\hline Jumlah praktek dokter & - \\
\hline Rumah bersalin & 1 \\
\hline $\begin{array}{c}\text { Balai kesehatan ibu dan } \\
\text { anak }\end{array}$ & 1 \\
\hline Rumah sakit mata & - \\
\hline
\end{tabular}

Sumber : Data Desa Sukamulya

Dari tabel diatas dapat dilihat bahwa sarana kesehatan masih tergolong minim dengan rasio penduduk, dalam hal ini, kepala desa selaku pimpinan harus dapat menyediakan sarana kesehatan sesuai dengan rasio penduduk dengan mengajukan pendirian sarana kesehatan kepada dinas terkait

Tabel 4.7

Pendidikan

\begin{tabular}{|c|c|c|c|}
\hline \multirow[b]{2}{*}{ Nama } & \multirow{2}{*}{$\begin{array}{c}\text { Juml } \\
\text { ah }\end{array}$} & \multicolumn{2}{|c|}{ Kepemilikan } \\
\hline & & $\begin{array}{c}\text { Pemerin } \\
\text { tah }\end{array}$ & $\begin{array}{c}\text { Swas } \\
\text { ta }\end{array}$ \\
\hline TK & 3 & - & 3 \\
\hline
\end{tabular}

\begin{tabular}{|c|c|c|c|}
\hline $\begin{array}{c}\text { SD/sederaj } \\
\text { at }\end{array}$ & 7 & 6 & 1 \\
\hline $\begin{array}{c}\text { SMP/seder } \\
\text { ajat }\end{array}$ & 1 & 1 & - \\
\hline $\begin{array}{c}\text { SMA/sede } \\
\text { rajat }\end{array}$ & 1 & - & 1 \\
\hline Ibtidayah & 2 & - & 2 \\
\hline $\begin{array}{c}\text { Tsanawiya } \\
\text { h }\end{array}$ & 1 & - & 1 \\
\hline Ponpes & 3 & - & 3 \\
\hline
\end{tabular}

Sumber : Data Desa Sukamulya

Dari tabel diatas dapat dilihat bahwa sarana pendidikan milik pemerintah masih tergolong rendah, dibandingkan dengan milik swasta, untuk sekolah menengah, sebaiknya kepala desa selaku pimpinan, menambah sekolah milik pemerintah dengan mengajukan pendirian sarana pendidikan kepada dinas terkait.

\section{Potensi Alam}

Tabel 4.8

Sumber air bersih

\begin{tabular}{|c|c|c|}
\hline Jenis & Jumlah & $\begin{array}{c}\text { Pemakaian } \\
\text { (KK) }\end{array}$ \\
\hline $\begin{array}{c}\text { Mata } \\
\text { Air }\end{array}$ & 2 & 56 \\
\hline $\begin{array}{c}\text { Sumur } \\
\text { Gali }\end{array}$ & 1346 & 2801 \\
\hline $\begin{array}{c}\text { Sumur } \\
\text { pompa }\end{array}$ & 105 & 105 \\
\hline Sungai & 1 & 105 \\
\hline $\begin{array}{c}\text { Depot } \\
\text { isi ulang }\end{array}$ & 4 & 205 \\
\hline
\end{tabular}

Sumber : Data Desa Sukamulya

Dari tabel diatas, sumber air bersih di dominasi oleh sumur gali. Sumber air tanah tergolong masih cukup baik. 
Tabel 4.9

Potensi Ternak

\begin{tabular}{|c|c|}
\hline Jenis ternak & $\begin{array}{c}\text { Jumlah } \\
\text { populasi }\end{array}$ \\
\hline Sapi & 38 \\
\hline Kerbau & 121 \\
\hline Ayam kampung & 1063 \\
\hline Ayam boiler & 35000 \\
\hline Bebek & 15000 \\
\hline Kambing & 464 \\
\hline Domba & 435 \\
\hline Angsa & 44 \\
\hline
\end{tabular}

Sumber : Data Desa Sukamulya

Dari tabel diatas dapat dilihat bahwa usaha peternakan ayam broiler tergolong tinggi dan cukup berhasil, kepala desa selaku pimpinan dapat mendorong para peternak ayam broiler ini supaya bisa lebih meningkatkan hasilnya dengan cara memberikan bantuan modal dan sejenisnya.

Tabel 4.10

Komoditas pangan

\begin{tabular}{|c|c|c|}
\hline Jenis pangan & Luas & $\begin{array}{c}\text { Hasil } \\
\text { panen }\end{array}$ \\
\hline Jagung & $2 \mathrm{Ha}$ & 4 ton/Ha \\
\hline Kacang tanah & $2 \mathrm{Ha}$ & 3 ton/Ha \\
\hline $\begin{array}{c}\text { Kacang } \\
\text { panjang }\end{array}$ & $15 \mathrm{Ha}$ & 3 ton/Ha \\
\hline Padi sawah & $35 \mathrm{Ha}$ & $\begin{array}{c}175 \\
\text { ton/Ha }\end{array}$ \\
\hline Padi lading & $2 \mathrm{Ha}$ & 6 ton/Ha \\
\hline Ubi kayu & $10 \mathrm{Ha}$ & $\begin{array}{c}500 \\
\text { ton/Ha }\end{array}$ \\
\hline Mentimun & $4 \mathrm{Ha}$ & 10 ton/Ha \\
\hline Terong & $1 \mathrm{Ha}$ & 25 ton/Ha \\
\hline
\end{tabular}

\section{Sumber : Data Desa Sukamulya}

Dari tabel diatas, komoditas pangan wilayah Desa Sukamulya masih tergolong baik

\section{KESIMPULAN}

Berdasarkan hasil wawancara dengan beberapa narasumber diantara nya Kepala Desa, Wakil Kepala Desa, Staf Desa dan beberapa masyarakat sekitar, maka dapat diperoleh data sebagai berikut

1. Sumber daya manusia masyarakat Desa Sukamulya masih tergolong rendah, dapat dilihat bahwa mayoritas penduduknya hanya tamat Sekolah Dasar

2. Mayoritas masyarakat Desa Sukamulya bermata pencaharian sebagai petani tradisional.

3. Masih minim sarana kesehatan seperti rumah sakit dan puskesmas sehingga kesadaran masyarakat untuk hidup sehat masih kurang layak.

4. Kondisi jalan yang rusak akibat banyaknya truk pengangkut pasir yang beroprasi sehingga minimnya sarana transportasi umum, untuk menghubungkan masyarakat Desa Sukamulya dengan masyarakat lain diluar Desa.

5. Lahan kosong disewakan kepada perusahaan eksploitasi pasir sehingga tingat polusi udara semakin kotor.

\section{SARAN}

Berikut saran-saran yang diberikan penulis setelah penulis melakukan penelitian untuk dapat dijadikan pertimbangan kepala desa dalam mengambil kebijakan demi tercapainya pembangunan desa sejahtera

1. Disarankan Kepala Desa mengembangkanpotensi sumber daya manusia, melalui pelatihan- 
pelatihan yang dilaksanakan oleh Desa.

2. Disarankan Kepala Desa mendorong masyarakat untuk mengenyam pendidikan yang lebih tinggi.

3. Disarankan Kepala Desa mendorong masyarakat untuk mengembangkan pengelolaan sawah melalui pembentukan usaha tani

4. Disarankan Kepala Desa mendorong masyarakat untuk berwirausaha untuk menambah pendapatan keluarga.

\section{DAFTAR PUSTAKA}

Akhmad Subekhi dan Mohammad Jauhar. 2012."Pengantar Manajemen Sumber Daya Manusia (MSDM)", Cet. Pertama, Prestasi Pustaka Raya: Jakarta.

As'ad, M. 2004. Psikologi Industri, Seri Umum. "Sumber Daya Manusia". Ed. 4. Liberty: Yogyakarta.

Bambang, Wahyudi. 2002. "Manajemen Sumber Daya Manusia”. Sulita: Bandung.

Byars, L. Lloyd and Leslie W. Rue. 2004. "Human Resource Management". 7thed., McGrawHill: New York.

Cascio. 2003. "Manajemen Sumber Daya Manusia". Cet. Ketujuh. Erlangga: Jakarta.
Danang Sunyoto. 2012. "Dasar-Dasar Manajemen Pemasaran". Cet. Pertama. CAPS: Yogyakarta.

G.R. Terry. 2001."Manajemen Dasar, Pengertian dan Masalah”,Ed. revisi, cet. 1, Penerbit Bumi Aksara: Jakarta.

Hamalik, Oemar. 2008. "Kurikulum dan Pembelajaran”. PT. Bumi Aksara: Jakarta.

H.A.R. Tilaar. 2009. Kekuasaan dan Pendidikan : "Kajian Menejemen Pendidikan Nasional dalam Pusaran Kekuasaan”. Jakarta: Rinika Cipta.

Hasibuan, Malayu. S. P. 2013. "Manajemen Sumber Daya Manusia”, PT. Bumi Aksara: Jakarta.

, 2007. "Manajemen Sumber Daya Manusia”, Ed. Cet. Kesembilan, PT Bumi Aksara: Jakarta. , 2000. "Manajemen Sumber Daya Manusia”. STIE YKPN: Yogyakarta.

Hughes, dkk. 2012. Leadership: "Memperkaya Pelajaran dari Pengalaman". Ed. 7. Salemba Humanika: Jakarta.

Lalu, Husni. 2003. "Pengantar Hukum Ketenagakerjaan Indonesia”. Ed. Revisi, Rajawali Pers: Jakarta. 
Luthans, Fred. 2006. "Perilaku Organisasi". (Alih Bahasa V.A Yuwono, dkk), Ed. Bahasa Indonesia, ANDI: Yogyakarta.

Mangkunegara Anwar,Prabu. 2013 "Manajemen Sumber Daya Manusia Perusahaan”, PT. Remaja Rosdakarya: Bandung. . 2009. "Manajemen Sumber Daya Manusia Perusahaan”, PT. Remaja Rosdakarya: Bandung. . 2000. "Manajemen Sumber Daya Manusia Perusahaan”. PT Remaja Rosdakarya: Bandung.

Manulang. 2003."Manajemen Personalia" Cetakan VI, Ghalia Indonesia.

Mathis Robert L. dan Jackson John H. 2006. "Human Resource Management". Alih Bahasa. Salemba Empat: Jakarta.

Pidarta, Made. 2004. "Manajemen Pendidikan Indonesia". Rineka Cipta: Jakarta.

Rachmawati, Hj Ike Kusdyah. 2007. "Manajemen Sumber Daya Manusia”. ANDI: Yogyakarta.

Rowe, W. Glenn and Guerrero, Laura. 2011. "Cases in Leadership". Second Ed. SAGE Publications, Inc: Thousand Oaks-California.

Sadili,Samsudin. 2009. "Manajemen Sumber Daya Manusia". Pustaka Setia: Bandung.
Simamora, Henry. 2014. "Manajemen Sumber Daya Manusia”.Cet. Kedua, STIE YKPN: Yogyakarta

Siswanto, Bedjo Sastrohadiwiryo. 2001. "Manajemen Tenaga Kerja Indonesia Pendekatan Administratif dan Operasional". Bumi Aksara: Jakarta . 2012. "Memahami Penelitian Kualitatif". ALFABETA: Bandung.

Sugiyono. 2011. "Metode Penelitian Kuantitatif, Kualitatif dan $R \& D$,, Cet. Ke Tiga Belas, Alfabeta: Bandung. 